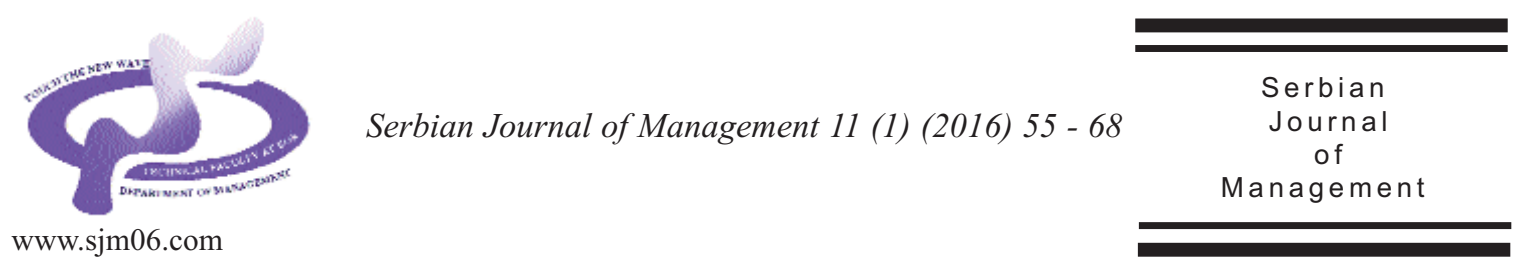

\title{
GOVERNING HIGHER EDUCATION INSTITUTIONS IN SINGAPORE: AN AGENCY FRAMEWORK
}

\author{
Choon-Yin Sam* \\ PSB Academy, 355 Jalan Bukit Ho Swee, Singapore 169567
}

(Received 2 January 2015; accepted 9 September 2015)

\begin{abstract}
It is widely known that governments are changing their relationships with public sector organizations with the aim of improving public sector efficiency and effectiveness. The conceptual understanding of government control and governance approaches in state-owned higher education institutions (HEIs) is, however, less well understood. Undoubtedly, question of the extent of autonomy and control of higher education institutions is of significant interest to administrators and policy-makers. This paper reviews the reforms undertaken by the Singapore government in HEIs especially the university sector. The agency framework is applied to assess the internal and external monitoring mechanisms aimed to protect the interest of the public. The paper finds that there is still much state presence and intervention in HEIs' activities despite the government's attempt to develop autonomous universities. Strengthening the corporate governance standard of the HEIs will offer a useful means to increase the willingness of the government to give more control to the HEI administrators.
\end{abstract}

Keywords: accountability, agency theory, higher education, Singapore

\section{INTRODUCTION}

Many academics have claimed that accountability of higher education institutions to external parties endangers academic freedom to pursue research and teaching without fear of intervention, preferring to insulate the higher education system from government steering despite its dependent on public funds to finance expenditure programs (Christensen, 2011; Enders et al., 2013). On the other hand, it is

\footnotetext{
* Corresponding author: choon-yin.sam@psb-academy.edu.sg DOI:10.5937/sjm11-7497
} 
well known that access to higher education represents a public good for the society. In this regard, state involvement is deemed necessary, by means of subsidy and institutional instruments to channel actions of decision-makers to certain directions, to achieve equality of opportunity for individuals of various backgrounds to gain access to education, and to fulfill collective public goals (Hayrinen-Alestalo \& Peltola, 2006; Dobbins et al., 2011; Christopher, 2014). Corporate scandals since the 2000s in the United States and elsewhere further remind us that some regulations are required to prevent improper practices and behavior.

The influence of the three forces academic freedom, state control and market forces - on higher education institutions' (HEIs) governance arrangements is aptly captured in Burton Clark's triangle (Figure 1) (Clark, 1983). The sharp ends of the shape show the forces that are capable of shaping the way HEIs behave. The forces are state, market and profession. The framework offers a useful tool to describe the path taken by HEIs. For example, countries such as the UK have taken the path of moving from a strong self-regulatory tradition to a more state and market regulation. In Singapore, the corporatization of the universities in 2006 represents a path taken by the city state

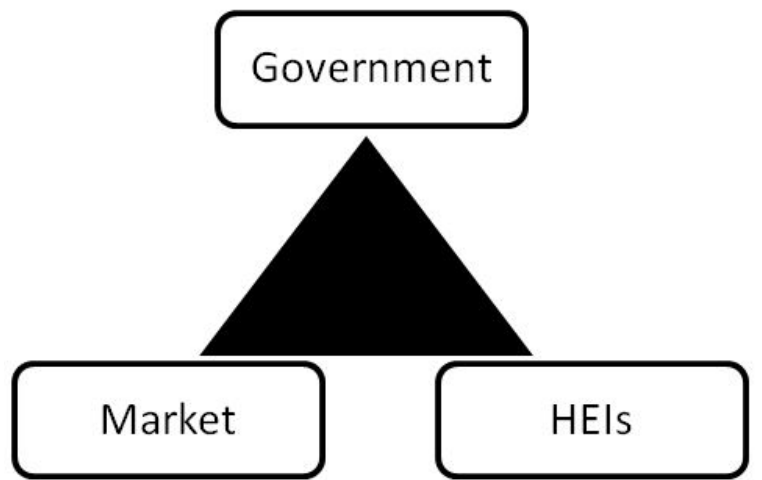

Figure 1. Clark's Accountability Triangle to transition from state-oriented model to a decentralized and more market oriented model.

Table 1 extends Burton's model by showing the key features of HEIs that are state-centred, market oriented and selfregulated. In the state-centred model, the state is the dominant decision maker. HEIs are state-owned corporations with a primary mission of meeting socio-economic objectives. In the market-centered model, HEIs are subjected to market pressure to become more service orientated towards students as customers and rely on market forces to achieve greater efficiency in resource allocation. The onset of Christopher Hood's 1991 paper which led to the growth of the New Public Management (NPM) paradigm in the $1980 \mathrm{~s}$ led to the incorporation of market based features in the HEI sector such as competition for students and research funds etc. (Hood, 1991). There is a widespread recognition that HEIs have to learn to be more entrepreneurial in working with the industry and to oversee and update curriculum, teaching pedagogy and assessment techniques to match change areas. The market-oriented reforms are meant to make the institutions more flexible and competitive by international standards.

The self-governance approach is akin to Wilhelm Humboldt's vision to impose free scholarly enquiry with strong self-regulation and collegial control by the professoriate in academic affairs. It should be noted that even in the Humboldtian tradition where universities are considered as administrative bodies with a special status and high actual autonomy the role of the government in education has never been doubted. As welfare economists would have reminded us, state intervention is necessary to finance the expenditure programs of the HEIs, and to 
Table 1. Governance models

\begin{tabular}{|c|c|c|c|}
\hline & State-centred model & $\begin{array}{l}\text { Market-oriented } \\
\text { model }\end{array}$ & $\begin{array}{l}\text { Academic self- } \\
\text { governance }\end{array}$ \\
\hline Agents & State/policy makers & Entrepreneurs & Peers \\
\hline $\begin{array}{l}\text { Governance } \\
\text { approach }\end{array}$ & Bureaucratic & Market forces & Collegial \\
\hline Primary mission & $\begin{array}{l}\text { Satisfying state socio- } \\
\text { economic objectives }\end{array}$ & $\begin{array}{l}\text { Provision of services } \\
\text { to academic } \\
\text { consumers; satisfying } \\
\text { market demands }\end{array}$ & $\begin{array}{l}\text { Academic freedom } \\
\text { and long-term } \\
\text { commitment to the } \\
\text { production of } \\
\text { knowledge }\end{array}$ \\
\hline $\begin{array}{l}\text { Who } \\
\text { controls/evaluates? }\end{array}$ & Ministry & $\begin{array}{l}\text { State/quasi } \\
\text { governmental; } \\
\text { accreditation bodies }\end{array}$ & $\begin{array}{l}\text { Self-evaluation by } \\
\text { university, academic } \\
\text { peers (within broad } \\
\text { framework } \\
\text { established by the } \\
\text { state) }\end{array}$ \\
\hline $\begin{array}{l}\text { Orientation of } \\
\text { teaching/research }\end{array}$ & State defined & Market demands & $\begin{array}{l}\text { Scientific } \\
\text { advancement }\end{array}$ \\
\hline Main funding base & State budget & $\begin{array}{l}\text { Competitive and } \\
\text { diversified (fees, } \\
\text { donations, research } \\
\text { grants, private } \\
\text { entities, state) }\end{array}$ & State budget \\
\hline
\end{tabular}

Source: Adapted from Fielden (2008)

internalize the externality problem although the extent of government intervention is correspondingly higher for primary and secondary education. ${ }^{1}$ It is also worth noting that regardless of whether the university is privately or publicly owned, the HEI is often pressured by potential students, parents and politicians to lower tuition fees and accept students from lower income families, so the extent of independence has not been as extensive as one would presume (Ehrenberg, 2013). The form of intervention from the state has transformed in the last two decades, from 'state-control' to 'state-supervision' with state playing the role of a referee or mediator. The establishment of autonomous universities is a step toward this direction where state owned universities are offered greater independence in the day-to-day operations. To ensure that the universities are accountable to the principals, the state ensures that relevant external and internal monitoring mechanisms are put in place.

\section{THE CASE OF SINGAPORE WITH A PARTICULAR REFERENCE TO THE UNIVERSITY SECTOR}

In Singapore, the Higher Education Division of the Ministry of Education (MOE) overseas the provision of postsecondary education, which includes the polytechnics, the Institute of Technical Education (ITE), the autonomous and private universities and publicly subsidized institutions such as LaSalle College of the Arts and Nanyang Academy of Fine Arts

\footnotetext{
1 In a 'good society', as John Kenneth Galbraith argued, "every child must have access to and be required to receive a good elementary and secondary education... Thereafter as to higher education there must be full opportunity for achievement so far as aspiration seeks and ability allows. For all this, public resources must be available" (Galbraith, 1996: 73-74).
} 
(NAFA). There were two universities in Singapore in 1965, the year of independence - Nanyang University (1956) and University of Singapore (1962). The two universities merged in 1980 for the National University of Singapore (NUS). An engineering practice-oriented university, Nanyang Technological Institute (NTI) was established in 1981, and became a fullfledged University, Nanyang Technological University (NTU) in 1991.2

In 1997, the International Academic Advisory Panel (IAAP) endorsed the establishment of the third university to meet the demand for tertiary education and attract international students to meet Singapore's manpower needs. The third university, Singapore Management University (SMU) recruited its first class of business students in 2000 , in partnership with one of the best business schools, the Wharton School of the University of Pennsylvania. Singapore University of Technology \& Design (SUTD) was added to the list of universities in Singapore in 2010. SUTD focuses on technology and design in the disciplines of engineering, information systems and architecture to produce graduates who are innovators to bring ideas from the drawing board into the real economy (modelled after MIT in the United States and Zhejiang University in China).

In the National Day Rally speech 2012, Prime Minister Lee Hsien Loong announced the addition of Singapore Institute of Technology (SIT) and SIM University (UniSIM) as Singapore's fifth and sixth universities, following the recommendation by the Committee on University Education Pathways Beyond 2015 to provide a "new applied degree pathway". SIT aims to provide polytechnic students an option to obtain a university degree from well regard foreign universities (University of Manchester, University of Nevada, DigiPen Institute of Tech). UniSIM issues its own degree, which are to fit the needs of industry and businesses (applied degree pathway). From July 2013, UniSIM students could apply for tuition fee loan of up to $90 \%$ of the subsidized fees payable.

The Singapore government has set the target of reaching the Cohort Participation Rate (CPR) of $40 \%$ by 2020 , and the establishment of SIT and UniSIM and expansion of intakes in universities are key steps in achieving the goal (Ministry of Education, 2012). ${ }^{3}$ Comparatively speaking, Singapore's CPR is higher than that of Korea and $\mathrm{HK}$, but significantly lower than welfare centric European countries (Figure 2).

Admission to public universities in Singapore is highly competitive to avoid high dropout rates, a waste of public scarce resources, and lowering of degree standards. Nevertheless, the growth in student numbers is dramatic, averaging 5\% per annum. Strong enrolments in public universities were stimulated by (i) the expansion of primary and secondary education with a high quality of output, (ii) subsidies to higher education, and (iii) rising family incomes (Goh \& Tan, 2008). Local students account for $84 \%$ of the student enrolment in the last three years in each autonomous university as revealed by the Ministry of Education in its parliamentary reply. 4

Figure 3 shows that Singapore spends on average $1.1 \%$ of the GDP on tertiary education. Singapore spends about $3 \%$ of the GDP on education. Comparatively, Singapore's expenditure on tertiary education at $1.1 \%$ of the GDP is lower than that of the OCED countries (Figure 4). Singapore, however, spends more on tertiary education as a percentage of total public

\footnotetext{
2 See Cham (2014) for an interesting account of the NTU story.

3 Suppose the rate is $25 \%$. This means that one in four students from each Primary One cohort obtains a place in one of Singapore's publicly-funded universities.

4 Ministry of Education (2012), Foreign Students in Local Autonomous Universities. Parliamentary reply to a question raised by Nominated Member of Parliament, Yee Jenn Jong, on 16 October 2012.
} 


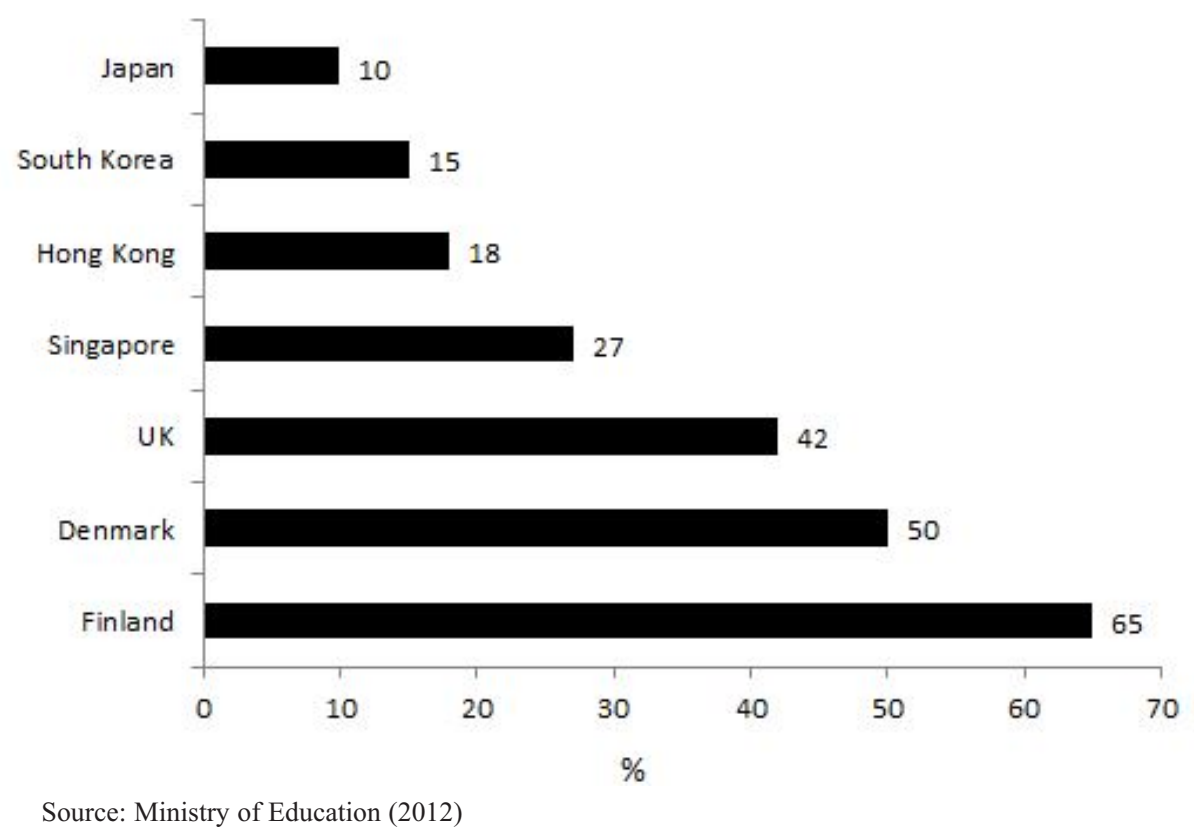

Figure 2. University's Cohort Participation Rate (2012)

expenditure $(7.1 \%$ for Singapore as compared to the OECD average of $3.1 \%$ ) (see Figure 5). As the Ministry of Education explains in a parliamentary reply, the OECD countries tax and spend more as a percentage of GDP, which leads to a larger base and smaller percentage of total public expenditure spent on tertiary education. The Ministry further points out that "recent OECD findings show that higher expenditure does not guarantee better student performance. The key to good outcomes for our students lies in the quality of teachers and the effective deployment of resources across the system". The correlation between education expenditure and performance of student appears muted, going by the performance of students in Mathematics and Science in international competitions which revealed that Singapore students performed "better than the OECD average". 5

Prior to the reforms undertaken in the university sector in Singapore, universities were structured as statutory boards. The cabinet members appointed the Vice Chancellors. University Councils, with representations from the private and public sector appointed by the government, set policies and made decisions. Faculty/administrative staff members were treated as government employees, with salary structure pegged to the civil service system. In addition, government approval is required for new programs, and clearance of course contents in which $30 \%$ is new content. Hiring, firing, and salary decisions are not independent of the Ministry of Education. And it is generally difficult for the management and university leadership to replace unproductive staff and reward productive staff.

Decentralization in the higher education sector was experimented with the establishment of SMU in 2000, which offers a test bed for the government. For one, SMU is able to determine admission criteria and tuition fees. Higher tuition fee and lower public subsidy have the effect of pressuring

\footnotetext{
5 Ministry of Education (2013) 'Government expenditure on education'. Parliamentary replies to a question raised by Nominated Member of Parliament, Janice Koh on 21 October 2013.
} 


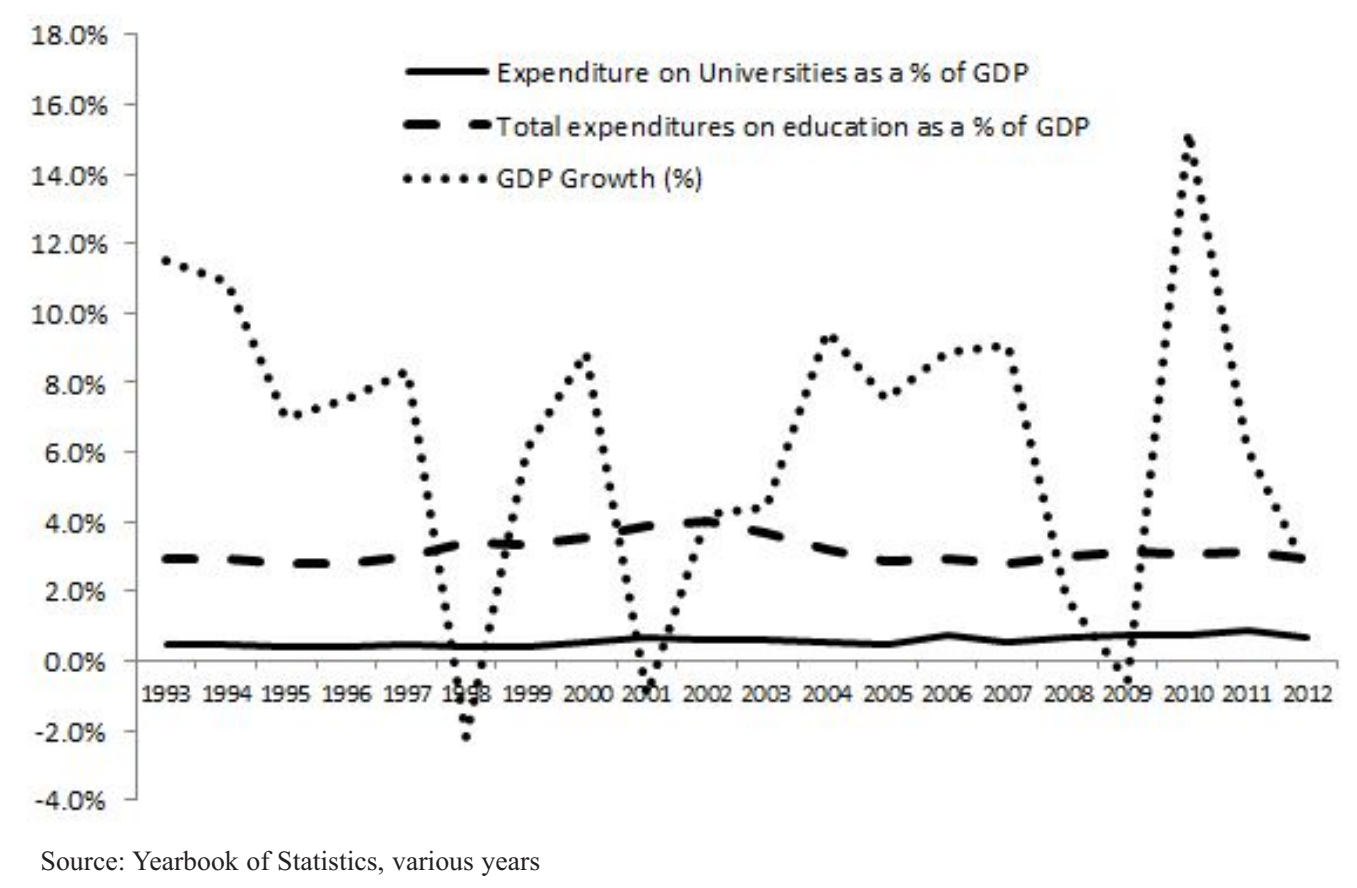

Figure 3. Government Expenditures on Education, Universities and GDP Growth (Singapore)

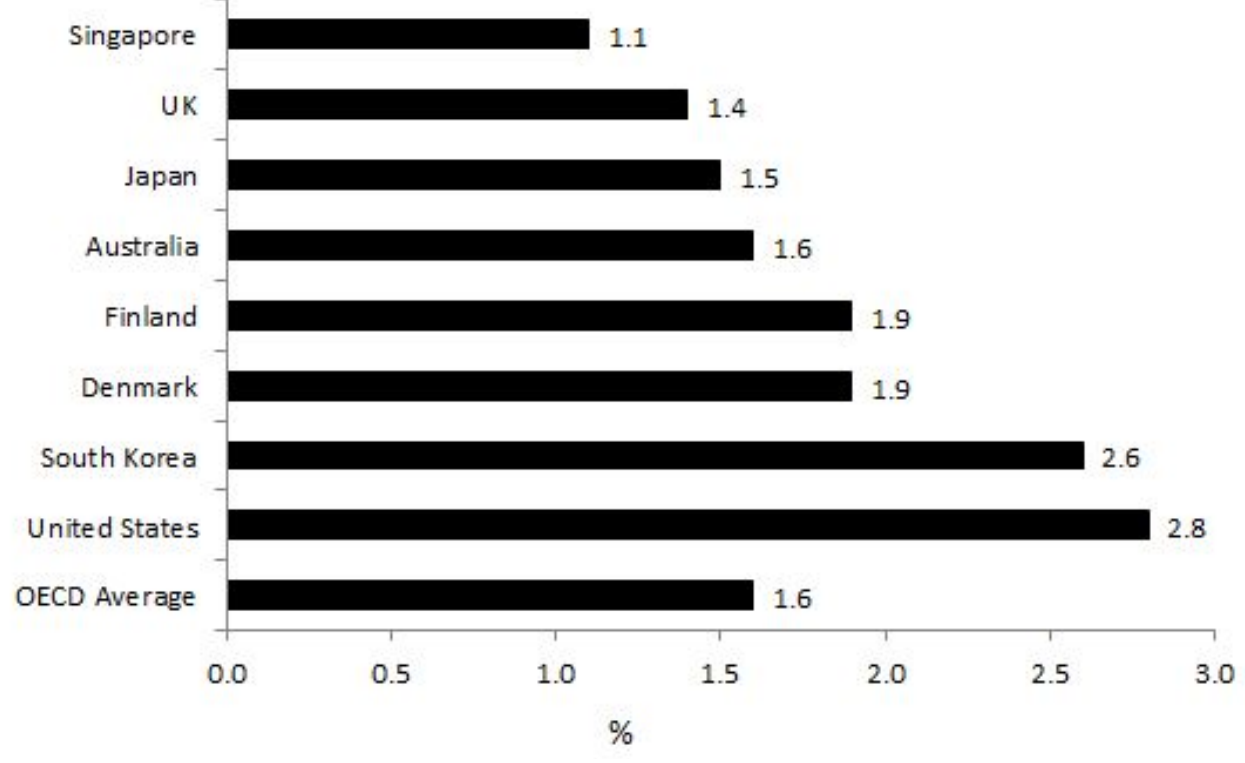

Source: Ministry of Education, Singapore (2012); OECD (2013)

Figure 4. Expenditures on Tertiary Education as a \% of GDP (2010)

the university to become more efficient in including high quality research contributions resource allocation. Celebrating the $15^{\text {th }}$ from the Schools that effectively placed the Anniversary of SMU in August 2014, its University and Singapore on the map of President Arnoud De Meyer proudly global rankings (the School of Economics, highlighted the achievements of SMU, for example, was ranked $1^{\text {st }}$ in Asia and 57th 


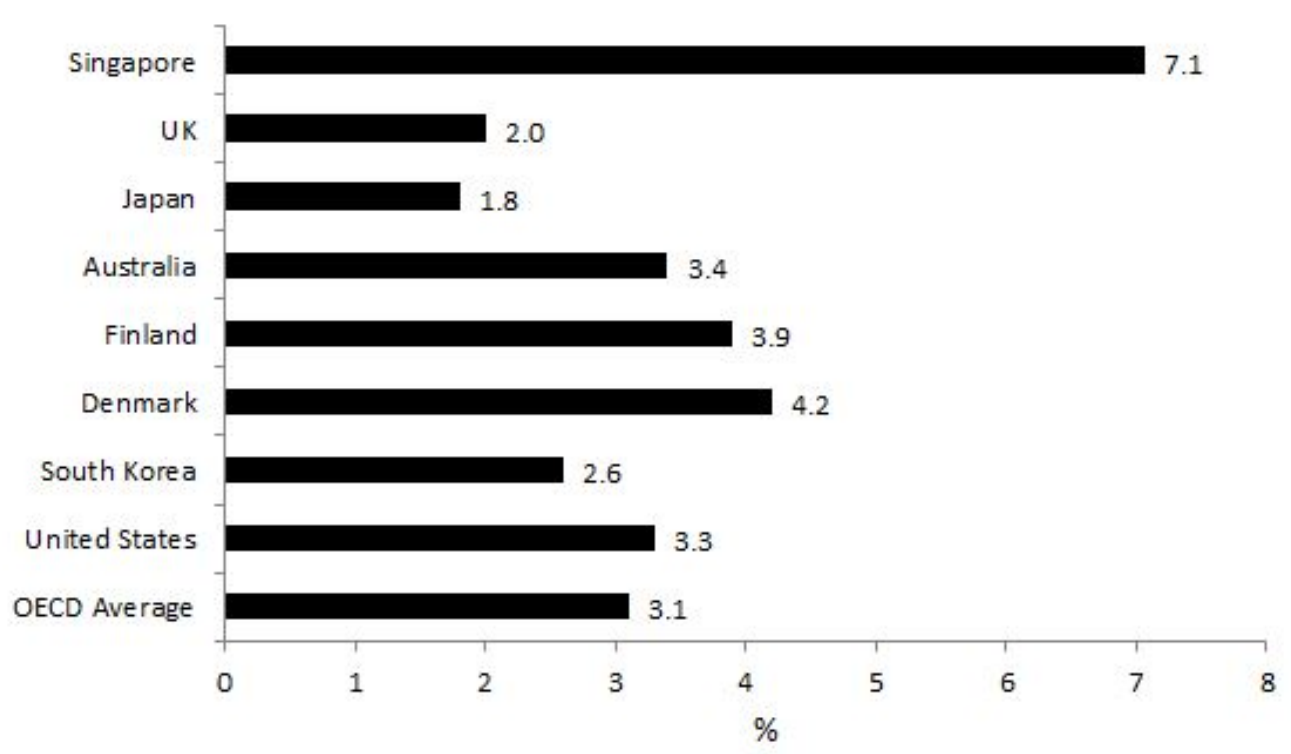

Source: Ministry of Education, Singapore (2012); OECD (2013)

Figure 5. Expenditures on Tertiary Education as a \% of Total Public Expenditure (2010)

in the World by Tilburg University Top 100 World Economics School Research Rankings). ${ }^{6}$ The story and success of SMU rationalizes the incorporation of major reform strategies in later part of the decade. The University Governance and Funding Review in 2000 recommended that greater autonomy be given to NUS and NTU to ensure that the universities remain competitive and relevant in the long run. The universities would have greater operational autonomy with regards to staff remuneration, and the University Councils would have more autonomy in setting strategic directions. Having assessed the experiences of NUS and NTU during the experimental period and the success of SMU, the government accepted the recommendations of the Steering Committee of University Autonomy, Governance and Funding Review (UAGF) in 2005 to corporatize NUS and NTU as non-for-profit corporations, with limited guarantee.

One may refer corporatization as the act of reorganizing the structure of government owned entity into a legal entity with the corporate structure that is typically found in publicly traded companies. The government is typically the corporatized firm's sole owner. Corporatized firms tend to put in place a management team to oversee the dayto-day matters and a board of directors to monitor the performance of the executive managers. With corporatization, universities have gained more flexibility, including startups research grants and reduced teaching load for top researchers.

In terms of course introduction, it can be argued that universities in Singapore have always been dependent on market signals in allocation of resources. They consider employers who hire the graduates, students and parents' choice for courses, and demand and supply of academic manpower in various specializations. Courses on computer science and computer engineering, for example, were introduced in the 1990s during the dot.com and information and computer technology boom. Similarly, the government anticipated the rise of biotechnology sector

\footnotetext{
6 SMU State of the University Adress (2014). Available online at http://www.smu.edu.sg/smu/about/university-information/stateuniversity-address-2014 (accessed on 29 December 2014).
} 
and planned for the polytechnics and universities to introduce courses in this field.

With corporatization, the universities are able to introduce programs relatively quicker than in the past in response to perceived needs. NUS launching of a new medical school in collaboration with Duke University of the United States in 2007 and introducing a new range of new educational programs in disciplines such as nanotechnology and interactive digital media are cases in point. Another example is the decision by NUS to offer two online courses on music and quantum tech through Coursera platform from Jan 2014 onward, leveraging on technology to boost and enhance digital learning skills in thinking and communication.

The extent of government control has been more relaxed with regards to human resource matters. As Wong Sek Man, then Acting Dean of the Science Faulty, NUS said, with corporatization, "....we have more discretion in hiring and firing matters. We can make quicker decisions in new appointments with the approval from the Provost instead of seeking the approval from the MOE" (Mok, 2010). But he added, "....the NUS senior management still follows the government's rule and regulations and only slow transformation has been experienced. Being deans and associate deans, I have not experienced major changes, let alone the ordinary faculty members" (ibid).

Tan Thiam Soon, Provost of the NUS, recounts a remarkable episode that offers a glimpse of the NUS-state relations. As Tan recalls, the Singapore MOE has once wanted NUS to increase the undergraduate intakes to meet the pressing demands for UG education from the Singapore citizens. NUS preferred to expand the postgraduate intakes to make
NUS more competitive. Confronted with the tension, NUS finally gave in and followed the admissions plan set out by MOE. To Tan, "It's NUS obligation to follow the government policy and we are not allowed to move away from the national plan even though we want to move" (Mok, 2010). The episode serves to remind that at the end of day, the university has to serve the national interest of Singapore even though the university has been granted the autonomous status. It can be deduced that the government wants to remain in control of the overall strategic direction taken by the universities especially with regards to the composition of students and funding.

\section{THE AGENCY THEORY IN THE EDUCATION SECTOR}

In the agency theory, agents are tasked to control the use of resources of the firm that they do not own. The principals are the rightful owners of the organization but they do not control the firm. There is a separation of ownership and control. The agency problem arises when the agents make decisions that maximize their personal interest rather than the interest of the principals they supposedly represent.

It can be argued that the agency theory is equally applicable in the education sector. With corporatization, the HEIs are effectively agencies of the state, utilizing taxpayers' money, to meet national objectives. The state (Minister for Education, to be more precise) in this regard represents the principals and HEIs represent the agents (See Figure 6). As a representative of the citizens of the country, the responsibility of the Minister is to ensure that taxpayers' money are not misappropriated by the HEIs' 


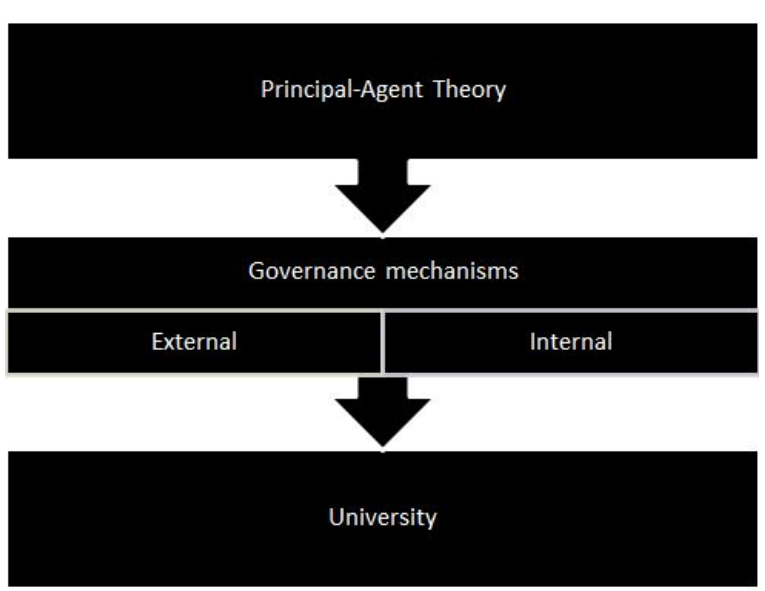

Source: Author

Figure 6. A conceptual framework

management team, and that proper checks are in place to monitor the performance of the HEIs' management team (King, 2007).

The control and monitoring of agents rest on two monitoring mechanisms - external and internal mechanisms. The external mechanisms are influences outside of the university. Complying with regulatory requirements in terms of fees setting and admission criteria is one form of controlling mechanism. It is also not unusual for the government to appoint the University Council members or Board of Trustees to oversee the activities of the universities. Other external monitoring mechanisms include more active role played by the anticorruption agencies (to investigate suspected persons for acting improperly), accreditation bodies (to provide independent assessments and ratings), judicial system (to provide effective legal protection to investors/shareholders) and the media (to provide information on private misdeeds by agents). Their task is to exert pressure on the agents to perform and maximize the longterm interest of the stakeholders. Internal controls can also play a role at mitigating the agency problem. This includes appointment of an independent board, appointment of a non-executive Chairman of the Board, separating the Chairman and the Chief Executive Officer (President of the University) and establishing incentive mechanisms (see MacAvoy \& Millstein, 2003 for a good summary of the measures).

\section{EXTERNAL AND INTERNAL MONITORING MECHANISMS IN HEI SECTOR IN SINGAPORE}

As the earlier section has alluded, with corporatization, it remains the government responsibility to ensure that taxpayers' money are not gone to waste or expropriated by HEIs' agents. After all, the government provides subsidies of about $75 \%$ of the total education cost at the universities. In the Singapore context, safeguarding public interest involves the following external mechanisms.

Firstly, the Minister for Education is granted the power to appoint/remove the Board of Trustees. In particular, Clause 5 of the NUS Corporation Act 2005 places national agenda at the top priority, which the universities are obligated to fulfil. The university administrators are therefore caught in the situation where they need to balance the wishes of the Board of publicly appointed Board of Trustees (as directed by the Minister for Education) and the interests of the faculty members. Specifically, the clause states that:

(1) The Minister may, in consultation with the university company, establish such policies on higher education in Singapore as the Minister thinks fit and may direct the university company to implement such policies.

(2) The university shall comply with any 
direction given by the Minister under subsection (1).

Second, the government ties public funding to policy agreement to be signed by the universities and MOE. The agreement stipulates the key policy parameters, including tuition fee setting, entry requirements, and cost control measures, that HEIs must abide. In the presence of pressure from students, parents and the government to contain the growth of tuition fees, an outcome of the agreement is that the universities would be compelled to allocate the resources more efficiently, which might include increased use of non-tenured track faculty (some studies have shown that the use of non-tenured track faculty would lead to lower graduation rates and diminished quality of education, see Ehrenberg \& Zhang, 2005) and closure of courses with low enrolment (such as foreign language programmes).

Third, the universities are subject to external review under the Quality Assurance Framework for Universities of the Ministry of Education. The panel, comprising independent local and international industry leaders, professionals and academics, evaluates the universities' self-assessment report and recommends areas for improvement. The universities are to address the recommendations raised by the panel and follow up with concrete actions plans. First launched in 2003, the QAFU is conducted once in five years.

Fourth, the Minister for Education is allowed full and free access to company's financial information. Clause 11 of the NUS Act states that the university shall, "as soon as the accounts of the University and the financial statements have been audited...send to the Minister a copy of the audited financial statements, signed by the
President of the University and the chief financial officer of the University, together with a copy of the author's report". The HEIs are answerable to Minister for Education. It is well known that an important reason for the agency problem to arise is the information asymmetry between the principals and agents where the latter have better knowledge about their ability and actions than the principals. By appointing the Minister for Education as the key monitoring agent, the agency problem may be moderated since the Minister stands a better chance of uncovering any improper practices.

The HEIs could also introduce and strengthen the internal monitoring mechanisms to monitor the functions and actions of the executive managers. The relevance of internal monitoring mechanisms is that the Board of Trustees and the Minister for Education may be willing to give more control to the university administrators in the presence of a high standard of corporate governance. To assess the internal mechanisms that have been put in place in the universities, one approach is to ask whether the universities have adopted the best practices of corporate governance in the private sector that cover aspects related to the size of the board, duties of the board members and dual leadership (separation of board Chairman and executive roles in the institution). The Annual Reports of the three universities - NUS, NTU and SMU - were reviewed to assess board meetings, processes and transparency in reporting.

As can be seen from Table 2, the board size of the three universities in Singapore ranges from 18 to 24 . This is at least comparable to the Australian universities. The study by De Silva and Armstrong (2012) revealed that in the case of the Australian 
Table 2. Internal Mechanisms

\begin{tabular}{lccc}
\hline & NUS & NTU & SMU \\
\hline Board of Trustees (number of members) & 24 & 18 & 18 \\
Chair is external & Yes & Yes & Yes \\
Chairman not the President & Yes & Yes & Yes \\
Existence of remuneration committee & Yes & Yes & Yes \\
Existence of nomination committee & Yes & Yes & Yes \\
Existence of audit committee & Yes & Yes & Yes \\
\hline
\end{tabular}

Source: NTU (2013); NUS (2013); SMU(2013)

universities, the board size reached the maximum of 22 council members and a minimum of 12 council members with a mean value of 19. In the private sector in the United States, the board size of the private sector corporations ranges from two to 22 , with an average of 15 members (Monks \& Minow, 2011). The higher average number of board members in the universities, Singapore inclusive, suggests that universities prefer to have larger governing bodies.

The three universities appoint an external person to Chair the Board, and the Chairperson is not the President of the University. In the National University of Singapore, for example, Wong Ngit Liong chairs the Board of Trustees whereas Professor Tan Chorh Chuan serves as the President to oversee the day-to-day matters in the university. The practice of having separate persons holding the two important positions is similar to a typical UK board in the private sector but different from that of the US where the same person normally holds the positions of Chairman and CEO (Conyon \& Murphy, 2000). In the case of Singapore, Mak and Phan (1999) reported that about $46 \%$ of the SES listed companies separate the posts of CEO and Chairman. MacAvoy and Millstein (2003) have argued that a Chairman who is not a CEO is able to "create meaningful agendas and call for management presentations around issues, not just around current problems that need resolution", and to "chair meetings with content rather than routine, based on position papers rather than reports" (MacAvoy \& Millstein, 2003).

Table 3 presents the results of the depth and extent of information disclosure. Ten measures, including reporting of strategic

Table 3. Does the Annual Report show the following?

\begin{tabular}{lccc}
\hline & NUS & NTU & SMU \\
\hline Vision and Mission & Yes & Yes & No \\
Strategic goal(s) & Yes & No & Yes \\
Expertise and skills of Trustees & Yes & No & No \\
Roles and responsibilities of Trustees & Yes & Yes & No \\
Meetings and attendance of meetings & No & No & No \\
Members of board committees & Yes & No & Yes \\
Disclosure of significant events & Yes & Yes & Yes \\
Student enrolment statistics & Yes & Yes & No \\
Statistics on graduates (such as Graduation Rate) & Yes & No & No \\
Financial performance & Yes & Yes & Yes \\
\hline
\end{tabular}

Source: NTU (2013); NUS (2013); SMU(2013) 
goals, financial performance, members of the board and graduation statistics, are considered and the results show that NUS scored the highest, fulfilling nine of the ten $(90 \%)$ reporting measures. NTU scored $50 \%$ and SMU scored 40\%. The NTU report contains detailed description of the financial performance but it is not particularly useful for the purpose of analyzing the internal governance mechanisms. The SMU report provides a remarkable list of activities conducted throughout the year in question, documenting its unique selling points rather than providing the assurance to readers and the general public that public funds have been safeguarded.

\section{CONCLUSION}

This paper shows that there is still much state presence and intervention in HEIs' activities especially with regards to financial matters and student enrolment. This is expected from the agency standpoint as it is the responsibility of the HEIs to serve the interest of the citizens (principals) who provided the financial capital. As far as the internal monitoring mechanisms are concerned, the universities have established the Board of Trustees and board committees, and appointed a separate person to head the Board, which are good practices to adopt. The results also show that the level of reporting for NTU and SMU has yet to fully comply with the best practices of governance that are typically found in publicly listed corporations. There is therefore room for improvement in the corporate governance standard of the HEIs, which will be essential to encourage and increase the willingness of the government in giving more control to the HEI administrators.

\section{УПРАВЉАЫЕ ИНСТИТУЦИЈАМА ВИСОКОГ ОБРАЗОВАЫА У СИНГАПУРУ: АГЕНЦИЈСКИ ОКВИР}

\section{Choon-Yin Sam}

\section{Извод}

Познато је да владе мењају своје односе са организацијама јавног сектора са циљем побољшања ефикасности и ефективности јавног сектора. Концептуално разумевање приступа владине контроле и управљања у државним институцијама високог образовања (HEIs) je међутим мање познато. Несумњиво, питање обима аутономије и контроле у институцијама високог образовања је од великог интереса за администраторе и законодавце. Овај рад разматра реформе које је предузела Влада Сингапура у високошколским установама, посебно у оквиру универзитета. Агенцијски оквир је примењен за процену механизама унутрашњег и спољашњег праћења са циљем да се заштити јавни интерес. У раду се констатује да су још увек веома изражени присуство и интервенција државе у активностима високошколских установа, упркос покушају владе да развије аутономне универзитете. Јачање стандарда корпоративног управљања високошколских установа ће понудити користан начин за повећање спремности владе да омогући већу контролу администраторима високошколских установа.

Кључне речи: одговорност, теорија агенција, високо образовање, Сингапур 


\section{References}

Cham, T.S. (2014). The Making of NTU: My Story. Singapore: Straits Times Press.

Christensen, T. (2011). University governance reforms: potential problems of more autonomy? Higher Education, 62, 503517.

Christopher, J. (2014). Australian public universities: are they practicing a corporate approach to governance? Studies in Higher Education, 39 (4), 560-573.

Clark, B. (1983). The Higher Education System: Academic Organization in Cross National Perspective. Berkeley: University of California Press.

Conyon, M.J., \& Murphy, K. (2000) The Prince and the Pauper? CEO Pay in the United States and the United Kingdom. Economic Journal, 110, 640-71.

De Silva L.C., \& Armstrong, A. (2012). Evaluation of corporate governance measures: an application to the Australian higher education sector. Journal of business systems governance and ethics, 7 (1), 76-86.

Dobbins, M., Knill, C., \& Vogtle, E.M. (2011). An analytical framework for the cross-country comparison of higher education governance. Higher Education, 62, 665-683.

Ehrenberg, R. (2013). Is the golden age of the private research university over? Change, 45 (3), 16-23.

Ehrenberg, R., \& Zhang, L. (2005). Do tenured and tenure-track faculty matter? Journal of Human Resources, 49 (3), 647 659.

Enders, J., de Boer, H., \& Weyer, E. (2013). Regulatory autonomy and performance: the reform of higher education re-visited. Higher Education, 65, 5-23.

Fielden, J. (2008). Global trends in university governance, Washington D.C.:
The World Bank.

Galbraith, J.K. (1996). The Good Society: The Humane Agenda. London: SinclairStevenson.

Goh, C.B., \& Tan, W.H. (2008). The development of university education in Singapore. In Lee, S.K., Goh, C.B., Fredriksen, B., \& Tan, J.P. (Eds) Toward a better future: education and training for economic development in Singapore since 1965. Washington D.C.: The World Bank.

Hayrinen-Alestalo, M., \& Peltola, U. (2006). The problem of a market-oriented university. Higher Education, 52, 251-281.

Hood, C. (1991). A Public Management for All Seasons? Public Administration, 69, 3-19.

King, R.P. (2007). Governance and accountability in the higher education regulatory state. Higher Education, 53, 411430.

MacAvoy, P.W., \& Millstein, I.M. (2003). The Recurrent Crisis in Corporate Governance. Hampshire: Palgrave MacMillan.

Mak, Y.T., \& Phan, P. (1999). Corporate Governance in Asia: A Comparative Perspective, Conference Proceedings Seoul, March 1999, OECD Report.

Ministry of Education, Singapore (2012). Report of the Committee on University Education Pathways Beyond 2015 (CUEP). Singapore: Ministry of Education.

Mok, Ka Ho (2010). When state centralism meets neo-liberalism: managing university governance change in Singapore and Malaysia, Higher Education, 60 (4), 419-440.

Monks, R., \& Minow, N. (2011). Corporate Governance (5th Ed). New York: Wiley \& Sons.

Nanyang Technological University (2013). Rising Elite Young: A Remarkable 
Ascent Annual Report 2013. Singapore:

Nanyang Technological University.

National University of Singapore (2013). National University of Singapore Annual Report 2013. Singapore: National University of Singapore.

OECD (2013). Education at a Glance. Paris: OECD.

Singapore Management University (2013). Annual Report to Stakeholders 2012/2013. Singapore: Singapore Management University. 